\title{
The potency of water availability and its use by the community around the Mount Merbabu National Park
}

\author{
Lugas Prasetyo $^{1}$ and Ambar Kusumandari ${ }^{2 *}$ \\ ${ }^{1}$ Alumny of the Faculty of Forestry UGM, FRCDepartment, Yogyakarta, Indonesia \\ ${ }^{2}$ Lecturer of the Faculty of Forestry, UGM, FRC Department, Yogyakarta, Indonesia
}

\begin{abstract}
Water is one of the basic needs for every living thing, including humans. This study aims to determine the availability of water in the two springs, the utilization of water by the community around MMNP, the vegetation characteristics of the spring catchment areas, and the Water Use Index (WUI). Data of water availability was taken using the volumetric method. Water utilization by the community is collected by doing the interviews with the respondents. The vegetation characteristics is analyzed based on the vegetation density by using the NDVI method. Meanwhile, the Water Use Index (WUI) is obtained from a comparison between water demand and water supply. The results showed that the water debit available in the Tuk Simuncar and Tuk sipendok was 23.22 liters/second and 31.20 liters/second which were classified as class IV. The area of Tuk simuncar is dominated by high density vegetation ( $75 \mathrm{Ha}$ ), while Tuk Sipendok is dominated by moderate density vegetation (102.28 Ha). The community around MMNP uses 211 liters of water for household needs, 59 liters for livestock, and 10 liters for agriculture. The Water Use Index (WUA) of the two springs has a value of 0.3 which is included in the low level.
\end{abstract}

\section{Introduction}

Water is an important element for the welfare of society. Currently there is increasing distance between population and water sources due to population growth, which is causing rapid expansion of some water networks. At the same time, global water consumption has quadrupled in the last 50 years and it is estimated that this value will continue to increase [1]. The water needed by all living things can naturally be provided by the forest.

Forest land use is usually associated with protecting water resources from contamination and reducing the cost of drinking water supply [2]. Stabilizing water supplies is one of the important functions of forests. Although forests consume large amounts of water as they grow, it increases the water storage capacity of the groundwater. Thus, functionally it becomes the largest water source in terrestrial ecosystems. In view of global water security issues and their relation to economic development, the importance of forests in maintaining water supplies in the current era is highly recognized [3]. Forests have a role as controller of the water cycle which has the concept of guaranteeing water yield. The amount of water that can be harvested is closely related to the availability of water in an area. Water availability is the volume of water contained in the hydrological cycle in an area, which is a combination of rainwater, surface water, and ground water [4].

The forest area in the Mount Merbabu National Park (MMNP) is one of the water catchment areas or water sources for the community at the foot of Mount
Merbabu. This is in accordance with the Decree of the Minister of Forestry No. SK.135/Menhut-II/2004, which states that the basis for determining the forest area on the slopes of Mount Merbabu to become a National Park area is a source of water for the surrounding community, protected flora and fauna habitat, and has attractive natural and cultural potential, so it is necessary to protected and preserved [5]. Thus, many springs in the Mount Merbabu area are used to support the lives of the surrounding community. Among them there are 2 springs that are used by the community in Boyolali Regency to meet their needs, namely Tuk Simuncar and Tuk Sipendok.

According to [6], communities from 13 villages bordering the Gunung Merbabu National Park in Boyolali Regency are dependent on forests for water extraction to meet their needs. Of the total people who use water in MMNP $89 \%$ of them use water directly from springs, either their own, neighbors or public wells whose water availability depends on water supply from Mount Merbabu. This makes the community around MMNP very dependent on water sources from the MMNP area. The disconnection of the clean water pipe network originating from Mount Merbabu, such as what occurred during a forest fire in the Mount Merbabu National Park area, made people have to take water from other hamlets [7]. This incident shows that the community around MMNP is very dependent on water sources on Mount Merbabu, including Tuk Simuncar and Tuk Sipendok.

Tuk Simuncar and Tuk Sipendok are springs located in the MMNP area, the two springs are used by 8 villages

\footnotetext{
* Corresponding author: ambar_kusumandari@ugm.ac.id
} 
in Boyolali Regency, namely Jeruk Village, Candisari Village, Kembang Village, Kembangkuning Village, Ngagrong Village, Ngargoloka Village, Sampetan Village, and Seboto Village. The eight villages rely heavily on water from the two springs to meet their needs. The high dependence of the community on Tuk Simuncar and Tuk Sipendok if not accompanied by adequate water availability can potentially disrupt community activities. Therefore, this research is needed that discusses the potential availability of Tuk Simuncar and Tuk Sipendok water in meeting the needs of the surrounding community. The purpose of this study was to determine the availability of water, vegetation characteristics of the spring catchment area, utilization, and the Water Use Index (IPA) in Tuk Simuncar and Tuk Sipendok Mount Merbabu National Parks.

\section{Material and methods}

\subsection{Location}

This research was conducted in August - December 2020 with locations, namely Tuk Simuncar and Tuk Sipendok water sources, as well as people who use both water sources, including: Jeruk Village, Kembangkuning Village, Ngagrong Village, Kembang Village, Seboto Village, Candisari Village, Ngargoloka Village, and Sampetan Village.

\subsection{Materials}

The materials used in this study are:

1. Two springs that are Tuk Simuncar and Tuk Sipendok discharge.

2. Land coverage of Mount Merbabu National Park.

3. Community who live surrounding the two springs.

The equipment used in this study consists of volumetric tools for discharge measurement, tally sheet, plastic, ruler, analytical scales, clinometer, roll meter, hagameter, tape meter, and camera.

\subsection{Methodes}

\subsubsection{Discharge}

Discharge data is taken using the volumetric method. This method is used to measure the flow rate of the two springs. In the volumetric method the entire flow in the study plot is collected in a container over a certain period of time. The discharge is expressed by Q (m3/s) which calculates the volume $\mathrm{V}(\mathrm{m} 3)$ at a certain time $\mathrm{t}$ (s), the discharge is read directly from the container or calculated indirectly [8].

The data that has been obtained then continues to process by using the following equations and classifications.

$$
\begin{aligned}
& Q=\frac{V}{t} \\
& \mathrm{Q}=\text { Discharge }(\mathrm{m} 3 / \mathrm{s}) \\
& \mathrm{V}=\text { Storage volume }(\mathrm{m} 3) \\
& \mathrm{t}=\text { Observation time }(\mathrm{s})
\end{aligned}
$$

Table 1. Classification of Spring Discharge According to Meinzer (1923) in [9].

\begin{tabular}{|l|l|}
\hline Class & Discharge \\
\hline I & $\geq 10 \mathrm{~m}^{3} / \mathrm{s}$ \\
\hline II & $1-10 \mathrm{~m}^{3} \mathrm{~s}$ \\
\hline III & $0.1-1 \mathrm{~m}^{3} / \mathrm{s}$ \\
\hline IV & $10-100 \mathrm{l} / \mathrm{s}$ \\
\hline V & $1-101 / \mathrm{s}$ \\
\hline VI & $0.1-1 \mathrm{l} / \mathrm{s}$ \\
\hline VII & $10-100 \mathrm{l} / \mathrm{s}$ \\
\hline VIII & $<10 \mathrm{l} / \mathrm{s}$ \\
\hline
\end{tabular}

Data on vegetation characteristics of the two springs catchment areas was obtained through remote sensing approach using the NDVI (Normalized Difference Vegetation Index) method which describes vegetation density and supervised classification to obtain a land cover map in the Gunung Merbabu National Park area. NDVI is a dimensionless index that describes the difference between visible and near infrared reflections from vegetation cover and can be used to estimate green density in an area of land [10]. Supervised classification is a classification of pixel values based on an example of a training area with known object types and spectral values [11]. The NDVI vegetation index that has been obtained is then classified based on previous research by [12] Dasuka et al. (2016) as shown in the following table.

Table 2 Value of NDVI

\begin{tabular}{|l|l|l|}
\hline Number & $\begin{array}{l}\text { Density } \\
\text { class }\end{array}$ & NDVI \\
\hline 1 & Low & $0.296-0.612$ \\
\hline 2 & Medium & $0.612-0.72$ \\
\hline 3 & High & $>0.72$ \\
\hline
\end{tabular}

Data regarding the use of springs by the community was collected by interview method. The interview method used is a structured interview using an interview guide. Structured interviews are interviews conducted by using by asking questions to respondents using questions that have been prepared or guide questions [13]. Based on data from Resort Ampel TNGMb water users Tuk Simuncar and Tuk Sipendok as many as 4.061. so that the number of samples obtained is 98 respondents. The Slovin formula used is as follows [14]. $\mathrm{n}=\frac{N}{1+N e^{2}}$

$\mathrm{n}=$ number of samples

$\mathrm{N}=$ total population

$\mathrm{E}=$ estimated error rate

The amount of water used by the community is obtained through the following formula.

Water needs/capita/day $=$ (water needs per family per day)/(number of family members)

The total water requirement of the population per day $=$ water demand/capita/day $\times$ the total population The population's water needs are also carried out by projecting population growth in 8 villages that use the Tuk Simuncar and Sipendok springs for the next 10 years. namely 2021 - 2031. Population growth projections are carried out using the arithmetic method. this method assumes that the population in the future 
will increase by the same amount every year [15]. The formula used in the arithmetic method is:

$P_{t}=P_{0}(1+r t)$

and $r=\frac{1}{t}\left(\frac{P_{t}}{P_{0}}-1\right)$

Information:

$\mathrm{Pt}=$ total population in year $\mathrm{t}$

$\mathrm{P} 0=$ total population in base year

$\mathrm{r}=$ population growth rate

$\mathrm{t}=$ time period between base year and year $\mathrm{t}$ (in years)

\subsubsection{Water Use Index (IPA)}

The Water Use Index (IPA) is a comparison between water demand and the existing water supply in a place [16]. IPA is used to determine the balance between water supply and community needs. The data used to obtain the IPA value comes from flow rate data as a water supply variable and data on the use of Tuk Simuncar and sipendok water by the community as a variable water demand. The value of IPA can be obtained using the following formula.

$\mathrm{IPA}=\frac{\text { Demand }}{\text { Supply }}$

The IPA value that has been obtained is then classified based on the Minister of Forestry Regulation No. P.61/Menhut-II/2014. as follows.

Table 3. IPA Classification

\begin{tabular}{|l|l|l|}
\hline Number & IPA & Class \\
\hline 1 & IPA $\leq 0.25$ & Very low \\
\hline 2 & $0.25<$ IPA $\leq 0.5$ & Low \\
\hline 3 & $0.5<$ IPA $\leq 0.75$ & Medium \\
\hline 4 & $0.75<$ IPA $\leq 1.00$ & High \\
\hline 5 & IPA $>1.00$ & Very high \\
\hline
\end{tabular}

\section{Results and Discussion}

\subsection{Water Availability at Tuk Simuncar and Tuk Sipendok}

Tuk Simuncar and Tuk Sipendok are two water sources located in the Mount Merbabu National Park area (Figure 1). The two water sources are included in the utilization zone of Mount Merbabu National Park. this is in accordance with the Minister of Forestry Regulation No. P.56/Menhut-II/2006. that the locations of water sources. especially those that have the potential to be utilized for the benefit of conservation. the community. and water service providers are indeed recommended to become zones for the use of water resources.

The existence of Tuk Simuncar and Tuk Sipendok at the Mount Merbabu TN area is in accordance with the statement of [17]. that the availability of water on Mount Merbabu is indeed abundant even in the long dry season. This is because Mount Merbabu is formed from pyroclastic rock (which is loose) and this landform can store water through former lava flows. However. Mount Merbabu is a rain shadow area so that in the dry season the water discharge is threatened to decrease. The amount of water discharge from Tuk Simuncar and Tuk Sipendok can be seen in the following table.
Table 4. Discharge of Tuk Simuncar and Tuk Sipendok

\begin{tabular}{l|l|l|l|}
\hline $\begin{array}{l}\text { Num } \\
\text { ber }\end{array}$ & Location & $\begin{array}{l}\text { Discharge } \\
(1 / \mathrm{s})\end{array}$ & Class \\
\hline 1 & Tuk Simuncar & 23.22 & IV \\
\hline 2 & Tuk Sipendok & 31.20 & IV \\
\hline * Classification of spring discharge according to \\
Meinzer (1923) in [9].
\end{tabular}

The table above shows that the available water discharge in Tuk Sipendok is greater than Tuk Simuncar. namely $31.20 \mathrm{lt} / \mathrm{s}$ and $23.22 \mathrm{lt} / \mathrm{s}$. Based on the classification of Meinzer (1923) in [9]. both water sources belong to the same class. namely class IV. The difference in flow rate in a spring is influenced by three factors. namely the permeability of the aquifer (ground water level). the recharge area that fills the aquifer. and the amount of ground water recharge (Davis \& de Wist. 1966 in [18]. From this statement. it is not surprising that the water discharge of Tuk Sipendok is greater than Tuk Simuncar because of its larger catchment area. which is 192.9 Ha compared to 137.6 Ha.The magnitude of the water discharge issued by Tuk Sipendok compared to the water discharge of Tuk Simuncar is in line with the large potential possessed by the two springs. This is in accordance with the statement of [7]. that the magnitude of a flow rate can be used to determine the potential of water to be utilized. so that the greater the discharge of a water flow. the greater its potential to support human activities. One of the reasons for choosing Tuk Simuncar and Tuk Sipendok as water sources for the community is because the two springs are included in the type of water flow that flows throughout the year or commonly called chronic springs. According to [19]. parennial springs are springs that release water throughout the year and are not affected by rainfall. so that people can take advantage of the flow of water throughout the year without worrying about losing water sources.

The existence of Tuk Simuncar and Tuk Sipendok needs to be preserved so that water supplies from both water sources remain sustainable. Preservation of water sources in the national park area. according to [20]. it can be done by providing clarity of regulations and policies by the manager so that there is a policy or agreement made between the manager and the water user. Efforts to maintain the sustainability of Tuk Simuncar and Tuk Sipendok can be realized through appropriate management strategies from the Gunung Merbabu National Park Office. According to the LongTerm Management Plan (RPJP) of Gunung Merbabu National Park for the 2019-2023 period. maintaining the availability of water resources is the first management goal. which includes Tuk Simuncar and Tuk Sipendok. The strategies owned by the Gunung Merbabu National Park Office regarding these objectives are periodic inventory and monitoring of water resources. facilitation of permits for the use of water resources. provision of supporting infrastructure. and provision of land cover maps.

According to the Minister of Forestry Regulation No. P.64/Menhut-II/2013. the volume of water that can be utilized from water sources within the national park area 
for non-commercial purposes is a maximum of $50 \%$ of the water volume that has been determined. so that according to the regulation. the flow data of Tuk Simuncar and Tuk Sipendok water volume that can be utilized is 11.61 liters/second and 15.6 liters/second. Determination of the volume of water utilization is carried out by taking into account the use of existing water. the carrying capacity of water resources. the number and distribution of the population around the area as well as the projected growth. calculation and projection of water resource needs. as well as objects and natural tourist attractions Utilization of water can only be carried out after obtaining a permit. in which a water utilization permit (IPA) can be submitted by government agencies. community groups. or social institutions. With this regulation. it is hoped that water user groups can apply for water utilization permits (IPA) from Tuk Simuncar and Tuk Sipendok so that the community has legality in using both water sources. Then. after the community groups apply for a water utilization permit (IPA). the Gunung Merbabu National Park Office can follow up by issuing water utilization permits (IPA) for Tuk Simuncar and Tuk Sipendok in accordance with applicable regulations.

\subsection{Vegetation characteristics}

In accordance with the management mandate of Mount Merbabu National Park. the existence of forests in Mount Merbabu National Park is an area that acts as a water catchment area. In the hydrological cycle. forest is a subsystem that has a function to be able to maintain the continuity of flow and the quality of the water that comes out (water yield). This is a role given by the density. composition and structure of forest vegetation and litter on the forest floor which makes it easier for water to enter the soil. thereby increasing the capacity of groundwater storage [21].

In accordance with the management mandate of Mount Merbabu National Park. the existence of forests in Mount Merbabu National Park is an area that acts as a water catchment area. In the hydrological cycle. forest is a subsystem that has a function to maintain the continuity of the flow and the quality of the water that comes out (water yield). This is a role given by the density. composition and structure of forest vegetation and litter on the forest floor which makes it easier for water to enter the soil. thereby increasing the capacity of groundwater storage [21].

It is important to know the vegetation density in the catchment area of the springs in order to ensure the availability of vegetation that acts as a water catcher and reservoir. In this study. vegetation density was obtained using the Sentinel 2 satellite imagery which was processed using the Normalized Difference Vegetation Index (NDVI) method. Sentinel 2 satellite imagery was chosen because it is based on spatial and temporal resolution according to research needs. According to ESA (2018) in [22]. Sentinel 2 imagery has a spatial resolution ranging from $10 \mathrm{~m}$ and a temporal resolution of 10 days with one satellite and 5 days with 2 satellites. NDVI is an index that is often used to determine vegetation density through level of greenery or the photosynthetic activity of vegetation. The NDVI vegetation index is based on the association of red and infrared waves so that it can display the greenness index of vegetation.

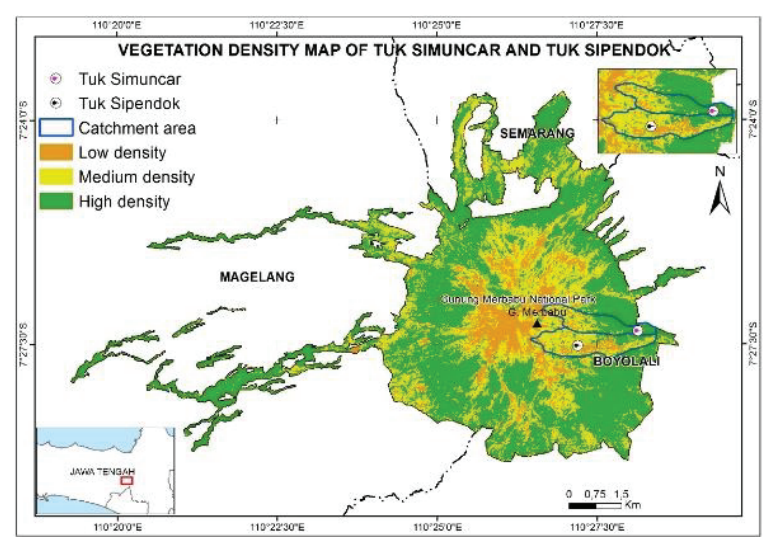

Figure 1. Vegetation density map

Table 5. Number of NDVI Pixels of the Springs Area

\begin{tabular}{|l|l|l|l|l|l|l|}
\hline \multirow{2}{*}{$\begin{array}{c}\text { Num } \\
\text { ber }\end{array}$} & \multirow{2}{*}{$\begin{array}{l}\text { Vegetati } \\
\text { on } \\
\text { density }\end{array}$} & NDVI & $\begin{array}{l}\text { Tuk } \\
\text { pixels } \\
\text { Sim } \\
\text { unca } \\
\text { r }\end{array}$ & $\begin{array}{l}\text { Tuk } \\
\text { Sipen } \\
\text { dok }\end{array}$ & $\begin{array}{l}\text { Tuk } \\
\text { Simu } \\
\text { ncar }\end{array}$ & $\begin{array}{l}\text { Tuk } \\
\text { Sipend } \\
\text { ok }\end{array}$ \\
\hline 1 & Low & $\begin{array}{l}0.296- \\
0.612\end{array}$ & 312 & 1051 & 12.48 & 42.04 \\
\hline 2 & medium & $\begin{array}{l}0.612- \\
0.2\end{array}$ & 1298 & 2557 & 51.92 & 102.28 \\
\hline 3 & high & $>0.72$ & 1875 & 1291 & 75 & 51.64 \\
\hline
\end{tabular}

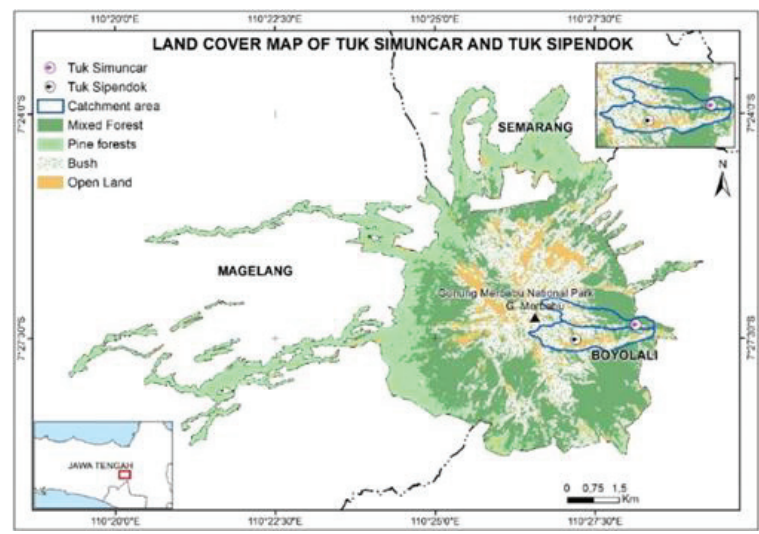

Figure 2. Land Cover Map of Mount Merbabu National Park

The picture above shows that the vegetation that grows in the Tuk Simuncar and Tuk Sipendok catchments is mixed forest. pine forest. and shrubs. Based on Table 6. the composition of land cover in the Tuk Simuncar catchment consists of mixed forest covering an area of $53.95 \mathrm{Ha}$ with a percentage of $39.6 \%$. pine forest covering an area of $2.14 \mathrm{Ha}$ with a percentage of $1.6 \%$. shrubs covering an area of $69.24 \mathrm{Ha}$ with a percentage of $50 . .8 \%$. and 10.86 hectares of open land with a percentage of $8 \%$. Meanwhile. the land cover in the Tuk Sipendok DTA consists of mixed forest covering an area of $30.27 \mathrm{Ha}$ with a percentage of $15.7 \%$. pine forest covering an area of $7.28 \mathrm{Ha}$ with a percentage of $3.8 \%$. shrubs covering an area of 117.52 Ha with a percentage of $60.9 \%$. and open land area of 
$37.87 \mathrm{Ha}$ with a percentage of $19.6 \%$. Mixed forest has a relationship with water management. namely when it rains on mixed forest land cover. various crown and root stratifications are able to hold and absorb water well so that the surface runoff formed is low [23].

Pine forest dominates the land cover in Mount Merbabu National Park because historically the Gunung Merbabu National Park area was formerly a Perhutani area which has the main commodity of pine stands. This pine forest. which has been widely developed on the island of Java since the Dutch colonial era. has controversy regarding its role as a regulator of water management. Pines are considered to cause drought in the dry season because they consume a lot of water. but on the other hand. pines have deep roots. playing a role in the process of interception and high evapotranspiration [24]. Shrubs as the land cover that dominates the Tuk Simuncar and Tuk Sipendok catchments are shrubs. Related to water management. shrubs are a type of land cover that has a low value in terms of soil moisture capacity to store water reserves or water holding capacity [25].

Table 6. Land Cover Composition in Tuk Simuncar and Tuk Sipendok catchments

\begin{tabular}{|l|r|r|r|l|}
\hline \multirow{2}{*}{$\begin{array}{l}\text { Land } \\
\text { coverage }\end{array}$} & \multicolumn{2}{|l|}{$\begin{array}{l}\text { Tuk } \\
\text { Simuncar }\end{array}$} & \multicolumn{2}{l|}{ Tuk Sipendok } \\
\cline { 2 - 5 } & $\begin{array}{l}\text { Area } \\
\text { (Ha) }\end{array}$ & \multicolumn{1}{l|}{$\%$} & $\begin{array}{l}\text { Area } \\
(\mathrm{Ha})\end{array}$ & $\%$ \\
\hline Pine forest & 2.14 & 1.6 & 7.28 & 3.8 \\
\hline Mixed forest & 53.95 & 39.6 & 30.27 & 15.7 \\
\hline Bush & 69.24 & 50.8 & 117.52 & 60.9 \\
\hline Bareland & 10.86 & 8.0 & 37.87 & 19.6 \\
\hline
\end{tabular}

Based on Table 5 and Table 6 . it can be seen that the Tuk Sipendok catchment area is dominated by vegetation with medium density and bushland cover. This condition was caused by forest fires that occurred in 2019. Fires that burned vegetated land caused the land to become open which was then overgrown by bushes. This situation can threaten the existence of Tuk Sipendok because it is prone to landslides. Therefore. the Gunung Merbabu National Park Office is expected to be able to educate the public on the importance of preventing forest fires. Another effort that can be made by Balai $\mathrm{TN}$ is to conduct stricter supervision so that people do not carry out activities in zones that are not permitted. such as jungle zones and core zones. The efforts of the Gunung Merbabu National Park Office must also be accompanied by awareness by the community not to carry out activities or carry items that can trigger forest fires such as burning grass and bringing matches.

\subsection{Water Utilization by Communities Around MMNP}

Communities around Mount Merbabu National Park are very dependent on springs in the Mount Merbbau National Park area. including Tuk Simuncar and Tuk Sipendok. This is because on the slopes of Mount Merbabu it is very difficult to make dug wells and drilled wells so that people only rely on water from the
Mount Merbabu NP area. including Tuk Simuncar and Tuk Sipendok. Tuk Simuncar is used by 10.493 people living in Candisari Village. Kembang Village. Ngargoloka Village. and Sampetan Village. while Tuk Sipendok is used by 13.551 people living in Jeruk Village. Kembang Village. Kembangkuning Village. Ngagrong Village. and Seboto Village.

Six of the eight villages that use water from Tuk Simuncar and Tuk Sipendok have used the PAMSIMAS (Community-Based Drinking Water and Sanitation Provision) management system. PAMSIMAS is one of the government programs (central and regional) with the support of the World Bank. to improve the supply of drinking water. sanitation. and increase the value and behavior of healthy living by building/providing sustainable community-based drinking water and sanitation facilities and infrastructure by the community. The PAMSIMAS program is implemented by the central government through the provision of assistance directly to the village level [26].

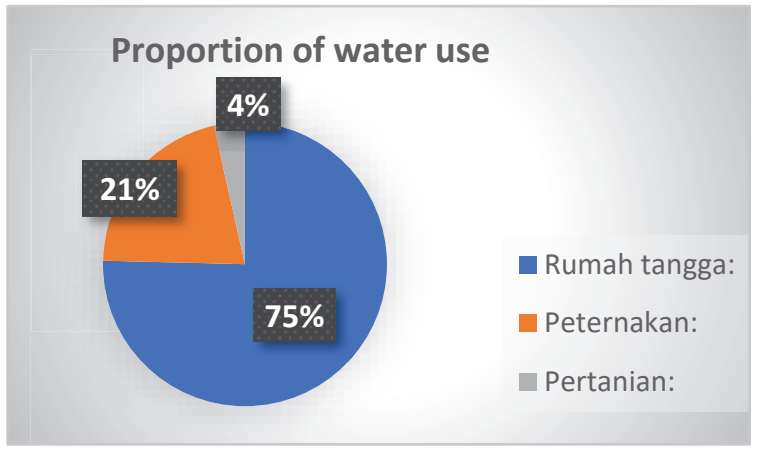

Figure 3 Proportion of water use for Tuk Simuncar and Tuk Sipendok

Based on the figure above. it can be seen that Tuk Simuncar and Tuk Sipendok are used by the community to meet household needs $(75 \%)$. livestock $(21 \%)$. and agriculture (4\%). Household needs dominate the community's water needs. Household needs require the most water because it is the basic need of every family in carrying out their activities.

Domestic water needs us a water used in private residences to meet daily needs. household water needs are used for drinking. cooking. bathing. washing toilets (MCK). washing cars/motorcycles. watering plants. and others [27]. Research by [28]. showed that household size. typology of residence. equipment efficiency. presence of children under 12 years of age. presence of a swimming pool and dishwasher are statistically significant variables affecting household water use. The need for water for households dominates the use of water by the community. This is in accordance with Law no. 17 of 2019 concerning Water Resources that the fulfillment of the right to water is prioritized for daily basic needs. smallholder agriculture. and the use of water resources for business needs to meet daily basic needs through a drinking water supply system. The use of water for household needs is important because it is a basic need for every human being to be able to carry out activities properly.

According to the data that has been obtained. at least every citizen who uses Tuk Simuncar and Tuk Sipendok 
needs 58 liters of water every day. The total water need of 58 liters per person is close to the water needs according to Table 1. which ranges from 60 - 80 liters / day. this adjustment is because the people who use water from Tuk Simuncar and Tuk Sipendok live in rural areas with a population of $<20.000$ people. However. according to Soedjoko (2011) in [29]. the availability of clean water which is the right of every human being is 50 liters/capita/day. so that when compared with this figure. the results of the study are appropriate.

In agriculture and animal husbandry. the Tuk Simuncar and Tuk Sipendok water users on average use 59 liters of water/day for agriculture and 10 liters/day for agriculture. The average community owns 2 cows. 5 goats. and 42 chickens. In the research area. livestock ownership is also influenced by the harvest season. as is the case when data collection is the tobacco harvest season. During the tobacco harvest season. many people sell their livestock because they are focused on taking care of the tobacco being harvested because it takes a lot of time. so the need for water for livestock can increase when people are not taking care of the harvest. While livestock water needs are influenced by plant age. based on interviews with farmers. water needs when plants are young is more than when plants are old. this is because when plants are young they need a lot of water to accelerate growth.

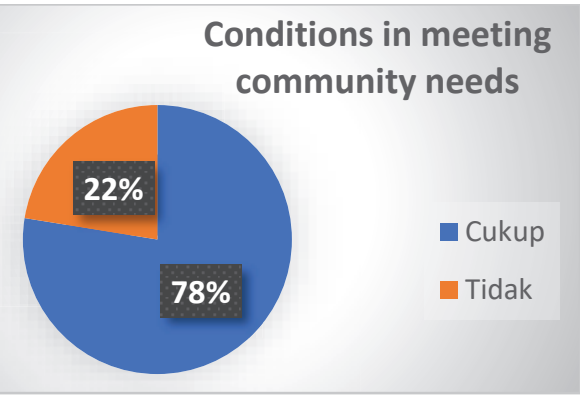

Figure 4. Percentage of Water Source Conditions in Meeting Community Needs

Through the picture above. it can be seen that as many as $78 \%$ of the community think that Tuk Simuncar and Tuk Sipendok are sufficient in meeting the needs of the community. while the other $22 \%$ think otherwise. Whether or not the water is sufficient or not is influenced by the village where they live. because the village they live in is related to the distance from the water source. The long distance from the water source can cause the water to not get to the residents' houses smoothly. Water that does not reach people's homes is caused by the height of the village compared to the water source. flow rate. and pipe leaks. According to [30]. the flow rate in a pipe is influenced by high pressure. pipe dimensions. pipe length. inlet dimensions. and outlet dimensions. Pipe leaks can be caused by water pressure that is too high and intentional by humans. this is done intentionally by making holes in the water pipe to be taken for the perpetrator's needs. such as watering the fields. Therefore. the placement of water pipes should be in locations that are often accessed by the public to minimize the possibility of pipe holes in the context of theft of water.
The high demand of the community for Tuk Simuncar and Tuk Sipendok water flows must be accompanied by good management as well. The availability of water for Tuk Simuncar and Tuk Sipendok can be maintained if the management is appropriate. including community management in making water networks. Although six of the eight villages that use water from Tuk Simuncar and Tuk Sipendok have been formed in the PAMSIMAS system. it needs to be accompanied by good communication between water user groups so that relations between groups run well and can exchange ideas in terms of supporting sustainable water use.

One way to maintain the sustainability of the Tuk Simuncar and Tuk Sipendok springs is to plan for proper water use. According to [31]. planning for the use of springs must be carried out by considering:

1. Long-term needs for springs. based on existing conditions of use and plans for developing springs in the future. so that they can be utilized sustainably.

2. The natural spring discharge is taken with the correct technique.

3. Benefit for the community. with the understanding that in addition to financial benefits. the use of springs must also provide social benefits. especially for people who have benefited before the springs were developed.

4. Conservation of catchment areas. to ensure the sustainability of the use of springs.

\subsection{Water Use Index (IPA)}

Water from Tuk Simuncar and Tuk Sipendok has been used by communities around Mount Merbabu National Park with a total of 10.493 users for Tuk Simuncar and 13.551 people for Tuk Sipendok. The number of water users needs to be adjusted to the availability of water in both water sources so as not to exceed their carrying capacity. One way to determine the suitability between the number of users and the available water is to monitor water use. According to the Minister of Forestry Regulation No. P.61/Menhut-II/2014. monitoring of water use is carried out to find out the description of the amount of water demand compared to the quantity of water available in a water flow.

Monitoring of water use can be done by calculating the value of the Water Use Index (IPA). The IPA value of a water flow is said to be good if the amount of water used in a water flow is still less than its potential so that the water flow still produces water that can come out to its downstream area. on the contrary it is said to be bad if the amount of water used is greater than its potential so that the volume of water used is produced from water sources for the downstream area are few or none [16]. The value of IPA in Tuk Simuncar and Tuk Sipendok can be seen in the calculation below:

$$
\begin{aligned}
& \text { IPA Tuk Simuncar }=\frac{\text { Demand }}{\text { Supply }} \\
& =\frac{\text { number of user } \mathrm{x} \text { demand of each person }}{\text { discharge } \times 86400} \\
& =\frac{10493 \times 58}{23.22 \times 86400} \\
& =0.3 \\
& \text { IPA Tuk Sipendok }=\frac{\text { Demand }}{\text { Supply }}
\end{aligned}
$$




$$
\begin{aligned}
& =\frac{\text { number of user } x \text { demand of each person }}{\text { discharge } \times 86400} \\
& =\frac{13551 \times 58}{31.20 \times 86400} \\
& =0.3
\end{aligned}
$$

3.5 Potential Water Availability in 2020 - 2029

The current water debit of Tuk Simuncar and Tuk Sipendok is still able to meet the needs of the surrounding community. but it is also important to know how the potential is for the future so that the management of water sources is in accordance with their designation. Over time. the community's water needs have the potential to change. which changes are related to the increasing number of people in the future. For this reason. it is necessary to do population projections to determine changes in the number of water users. The population projection in question is a population forecast based on a scientific calculation based on components that affect population growth in the future [15]. Population projections are carried out based on the number of residents in each village using Tuk Simuncar and Tuk Sipendok water for the last three years. The increasing number of water users must be adjusted to the available water debit in Tuk Simuncar and Tuk Sipendok.

According to Davis \& de Wist (1966) in [18]. the amount of flow discharge in a spring is determined by the amount of ground water filling. According to [32]. rain is the main source of groundwater. therefore in this study a spring discharge forecast was carried out based on rainfall data in the Tuk Simuncar and Tuk Sipendok catchments for the last 10 years obtained from the Chirps satellite with the help of Google Earth Engine.

Table 7. IPA of Tuk Simuncar Projections for $2020-2029$

\begin{tabular}{|l|l|l|l|l|l|}
\hline Year & User & $\begin{array}{c}\text { Water } \\
\text { demand } \\
(1 / \text { sec })\end{array}$ & $\begin{array}{c}\text { Water } \\
\text { supply } \\
(1 / \text { sec })\end{array}$ & IPA & Class \\
\hline 2020 & 9.784 & 6.57 & 23.22 & 0.3 & Low \\
\hline 2021 & 10.056 & 6.75 & 22.58 & 0.3 & Low \\
\hline 2022 & 10.328 & 6.93 & 21.94 & 0.3 & Low \\
\hline 2023 & 10.600 & 7.12 & 21.29 & 0.3 & Low \\
\hline 2024 & 10.872 & 7.30 & 20.65 & 0.4 & low \\
\hline 2025 & 11.143 & 7.48 & 20.01 & 0.4 & Low \\
\hline 2026 & 11.415 & 7.66 & 19.37 & 0.4 & Low \\
\hline 2027 & 11.687 & 7.85 & 18.73 & 0.4 & Low \\
\hline 2028 & 11.959 & 8.03 & 18.09 & 0.4 & Low \\
\hline 2029 & 12.231 & 8.21 & 17.44 & 0.5 & Medium \\
\hline
\end{tabular}

Table 7. shows that the number of Tuk Simuncar water users is projected to continue to increase until 2029 with a total of 12.231 users. of which it is predicted that 8.21 liters/second of water will be required to meet daily needs. To meet the water demand. it is predicted that in 2029 Tuk Simuncar's water discharge will be 17.44 liters/second. From the value of water demand and supply. it can be seen that the Tuk Simuncar Water Use Index (IPA) value in 2029 is 0.5 which is in the medium class. Medium class means that the amount of water taken from Tuk Simuncar has a proportion of $50 \%$ of the total discharge. so that there is still water flowing downstream.

Table 8. IPA of of Tuk Sipendok Projection for $2020-2029$

\begin{tabular}{|l|l|l|l|l|l|}
\hline Year & User & $\begin{array}{l}\text { Water } \\
\text { demand } \\
(1 / \mathrm{sec})\end{array}$ & $\begin{array}{l}\text { Water } \\
\text { supply } \\
(1 / \mathrm{sec})\end{array}$ & IPA & Class \\
\hline 2020 & 12.534 & 8.41 & 31.20 & 0.3 & Low \\
\hline 2021 & 12.779 & 8.58 & 30.34 & 0.3 & Low \\
\hline 2022 & 13.024 & 8.74 & 29.48 & 0.3 & Low \\
\hline 2023 & 13.268 & 8.91 & 28.61 & 0.3 & Low \\
\hline 2024 & 13.513 & 9.07 & 27.75 & 0.3 & Low \\
\hline 2025 & 13.757 & 9.24 & 26.89 & 0.3 & Low \\
\hline 2026 & 14.002 & 9.40 & 26.03 & 0.4 & Low \\
\hline 2027 & 14.247 & 9.56 & 25.16 & 0.4 & Low \\
\hline 2028 & 14.491 & 9.73 & 24.30 & 0.4 & Low \\
\hline 2029 & 14.736 & 9.89 & 23.44 & 0.4 & Low \\
\hline
\end{tabular}

Table 8 shows that the number of Tuk Sipendok water users is projected in 2029 to be 14.736 people with the amount of water needed at 9.89 liters/second and it is estimated that the available water in Tuk Sipendok is 23.44 liters/second. from this figure it can be seen that the value of IPA Tuk Sipendok in 2029 is estimated to be 0.4 or included in the low class. Low grade indicates that water taken from water sources has a proportion of less than $50 \%$ so that there is still a lot of water that can flow to the downstream area.

The need for water from both water sources tends to increase every year which is influenced by the dynamics of the population. While water supply is closely related to changes in rain patterns. [33]. changes in rain patterns and evapotranspiration in many tropical islands will cause changes in water resources. runoff and seasonal distribution patterns. The meeting between demand and supply of water indicates that the IPA value is equal to 1. or the water taken is equal to the supply. Based on Figure 20. it can be seen that IPA is estimated to be worth 1 in 2040 for Tuk Simuncar and 2042 for Tuk Sipendok.

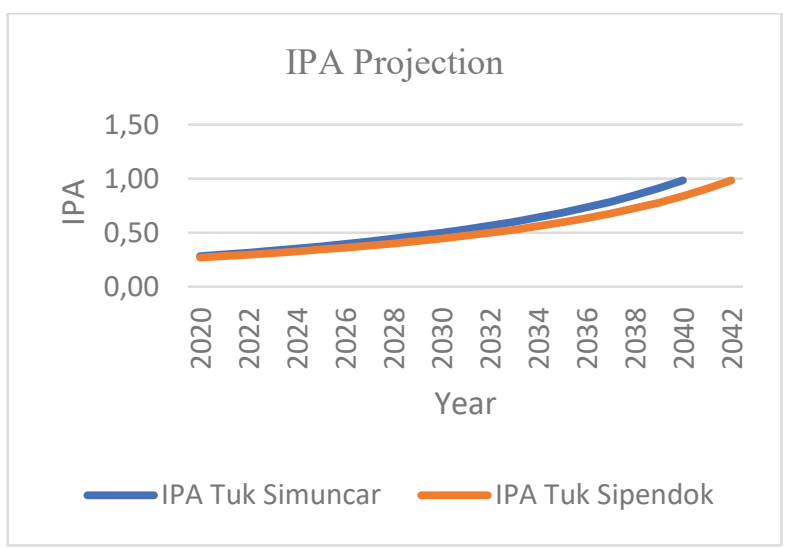

Figure 5. Graph of Projected IPA Values 
The availability of water for Tuk Simuncar and Tuk Sipendok in the future. apart from being determined by natural factors. also needs to be balanced with the efforts of the management of Mount Merbabu National Park (MMNP) and the community. related to the application of water conservation techniques. Water conservation through effective management and efficient use is an activity that is urgently needed and urgent. Water management based on its existence as a natural resource is part of a water conservation program that fully maintains. rehabilitates. maintains and utilizes existing water sources effectively and efficiently in order to play a role in improving people's welfare [34]. Water conservation is one of the main keys in ensuring water availability and increasing water supply in line with increasing demands for water [35].

The study of the available flow rate. the condition of the vegetation in the catchment area. the use of community water. and the balance between water demand and water supply can refer to the potential availability of water from Tuk Simuncar and Tuk Sipendok. From the flow rate data and community water utilization. it can be seen the IPA value which shows the comparison between demand and water supply. The known IPA value can indicate an opportunity for further utilization. if the IPA value is still low. it means that there is still an opportunity to utilize the available water more. Meanwhile. data on vegetation characteristics of water catchment areas is used to support the potential for water availability that can be owned by Tuk Simuncar and Tuk Sipendok. Good vegetation conditions such as having high density with mixed forest cover can increase soil aggregate and infiltration capacity. and reduce the threat of landslides.

\section{Conclusions}

Based on the description in this study. it can be concluded that:

1. The available water debits in Tuk Simuncar and Tuk Sipendok are 23.22 liters/second and 31.20 liters/second. The water discharge for the future may change according to natural conditions. based on the results of the projected water discharge at the two water sources. it is estimated that in 2029 the water discharge of Tuk Simuncar and Tuk Sipendok will decrease so that it has a water discharge of 17.44 liters/second and 23.44 liters/second. To maintain the sustainability of water sources. it is necessary to make regulations and policies related to the use of water by taking into account the applicable provisions.

2. The water catchment area of Tuk Simuncar is dominated by vegetation with a high density of $75 \mathrm{Ha}$. while at Tuk Sipendok it is dominated by vegetation with a medium density of $102.28 \mathrm{Ha}$. When viewed from the dominance of vegetation cover. both Tuk Simuncar and Tuk Sipendok are dominated by shrubs. Related to water management. shrubs are a type of land cover that has a low value in terms of soil moisture capacity to store water reserves or water holding capacity. With this condition. it is hoped that the Gunung Merbabu National
Park Center and the community can prevent land fires that can damage vegetation in the water catchment area. 3. Communities around Gunung Merbabu National Park use Tuk Simuncar and Tuk Sipendok water to meet household water needs (75\%). livestock (21\%). and agriculture $(4 \%)$. Of the total use of water. every day requires as much as 58 liters of water/person to meet their needs. Household needs are important because they are basic needs for every human being to be able to carry out activities properly. The use of water by the community around Mount Merbabu TN should be accompanied by permits that are in accordance with applicable regulations so that people get legality in using water from the Mount Merbabu TN area.

4. The Water Usage Index (IPA) of Tuk Simuncar and Tuk Sipendok is currently 0.3 . which is in the low class. This figure means that the amount of water taken by the two water sources is still relatively low. so it still leaves a lot of water to flow to the area below. The current IPA value is different from the projected IPA value in 2029. which is 0.5 (middle) for Tuk Simuncar and 0.3 (low) for Tuk Sipendok which indicates the increasing number of users but decreasing water supply.

The authors would like to thank for the support funding from RTA UGM year 2021 in facilitating the field data collection and presentation of this research. Special thanks to Mount Merbabu National Park Agency for giving the research permission at the study area.

\section{References}

1. B. Coelho, A. Andrade-Campos, Efficiency achievement in water supply systems - A review. Renewable and Sustainable Energy Reviews 30, $59-84$ (2014)

2. J. Fiquepron, S. Garcia, A. Stenger, Journal of Environmental Management 126, 113 - 121 (2013)

3. C. Lim, C. Song, Y. Choi, S. Woo Jeon, W. Lee, Journal of Environmental Management 248 (2019)

4. S. Sosrodarsono, K. Takeda, Hidrologi untuk Pengairan (Pradna Paramita, Jakarta, 2003).

5. Aditya, D.N. Gilang, M. Faddel, Sunarto, Pros Sem Nas Masy Biodiv 5(1), 362-368 (2019)

6. H. Gunawan, M. Bismark, K. Haruni, Jurnal Penelitian Hutan dan Konservasi Alam 10(2), 103-119 (2013)

7. A.N. Nugroho, M. Z. Faza, P.A. Winarso, Analisis Kondisi Meteorologi Terkait Kejadian Kebakaran Hutan di Lereng Gunung Merbabu, In Prosiding SNFA (Seminar Nasional Fisika dan Aplikasinya), 24 - 34 (2018)

8. M. Chang, Forest Hidrology Third Edition (CRC Press, London, 2013)

9. D.K. Todd, L. W. Mays, Groundwater Hydrology Third Edition (John Wiley \& Sons Inc., New Jersey, 2005)

10. L.H. Schinasi, T. Benmarhnia, A.J. De Roos, Environmental Research 161, 168 - 180 (2018)

11. N.H. Nawangwulan, S. Bambang, S. Bandi, Jurnal Geodesi Undip 2(2), 127-140 (2013) 
12. Y.P. Dasuka, S. Bandi, Hani'ah, Jurnal Geodesi Undip 5(2), 1-8 (2016)

13. U. Silalahi, Metode Penelitian Sosial (Rafika Aditama, Bandung, 2009)

14. N. Duli, Metodologi Penelitian Kuantitatif: Beberapa Konsep Dasar Untuk Penulisan Skripsi \& Analisis Data dengan SPSS (Budi Utama, Yogyakarta, 2019)

15. D. Handiyatmo, S. Idha, R. Hasnani, Pedoman Penghitungan Proyeksi Penduduk Dan Angkatan Kerja (Badan Pusat Statistik, Jakarta, 2010)

16. G. Oktavia, Y.L. Handayani, Siswanto, Jom FTEKNIK 5(2), 1-6 (2018)

17. Purwaningsih, Berk. Penel. Hayati Edisi Khusus 4A, 23-28 (2010)

18. S. Sofiah, P. F. Abban, Berk. Penel. Hayati Edisi Khusus 4A, 1-3 (2010)

19. S. Purnama, Hidrologi Air Tanah (Penerbit Kanisius, Yogyakarta, 2010)

20. A. Yuniarsih, D. Marsono, S. Pudyatmoko, R. Sadono, Jurnal Penelitian Hutan dan Konservasi Alam 11(3), 239-259 (2014)

21. L.P. Harahap, U.H. Angelia, Nilai Ekonomi Kelembagaan Menjaga Hutan dan Air untuk Irigasi (Puspantara, Medan, 2018)

22. D. Ariani, Y. Prasetyo, B. Sasmito, Jurnal Geodesi UNDIP 9(1), 207 - 216 (2020)

23. D.L. Setyowati, Forum Geografi 24(1), 39-56 (2010)

24. Y. Indrajaya, W. Handayani, Info Hutan 5(3), 231-240 (208)

25. N.B. Laksono, S. Suprayogi, Jurnal Bumi Indonesia, 8(3) (2010)

26. M.T. Astuti, M. Rahdriawan, Jurnal Teknik PWK, 2(4) (2013)

27. J.D. Putuhena, Pengelolaan Daerah Aliran Sungai (DAS) Dimensi Pengeloaan Berkelanjutan di Kota Ambon (Pascasarjana Manajemen Hutan Unpatti, Ambon, 2019)

28. K. Rathnayaka, S. Maheepala, B. Nawarathna, B. George, H. Malano, M. Arora, P. Roberts, Resources, Conservation and Recycling 92, 8594 (2014)

29. Sepsiaji, D. Nurhadi, Awang S. A. dan W. Andayani, Kelangkaan Air: Mitos Sosial. Kiat. dan Ekonomi Rakyat (DEBUT Press, Yogyakarta, 2005)

30. E. Sulistyanto, K. Suharno, S. Widodo, Wahana Ilmuwan 2(2), 13-22 (2016)

31. S. Arsyad, E. Rustiadi, Penyelamatan Tanah. Air. dan Lingkungan (Yayasan Obor Indonesia, Jakarta, 2008)

32. S.D. Devy, H. Heru, P.E.P. Dony, Pemodelan Airtanah Daerah Penambangan Batubara Pit Terbuka Di Muara Lawa. Kabupaten Kutai Barat. Kalimantan Timur, In Prosiding Seminar Nasional Kebumian Ke-7 Jurusan Teknik Geologi, Fakultas Teknik Universitas Gadjah Mada, 30 - 31 Oktober (2014)

33. R.M. Delinom, D. Marganingrum, Sumber Daya Air dan Lingkungan: Potensi, Degradasi, dan Masa Depan (LIPI Press, Jakarta, 2007)

34. M.K. Sallata, Info Teknis Eboni 12(1), 75-86
(2015)

35. R.J. Kodoatie, S. Roestam, Tata Ruang Air (Andi, Yogyakarta, 2010) 